\title{
Electroencephalograms in a Case of Maple Syrup Urine Disease: Their Relation to Serum Levels of Branched-Chain Amino Acids*
}

\author{
Kazuie Imnuma, Takashi Satto, Yoshroo Wada, Aktra Onuma, \\ Norimitsu Takamatsu, Hiromi Otomo and Yukio Kolzumr $\dagger$ \\ Department of Pediatrics, Tohoku University School of Medicine, \\ Sendai and + Hitachi General Hospital, Hitachi
}

Invuma, K., Satto, T., Wada, Y., Ondma, A., Takamatsu, N., Otomo, H. and KoIzUm, Y. Electroencephalograms in a Case of Maple Syrup Urine Disease: Their Relation to Serum Levels of Branched-Chain Amino Acids. Tohoku J. exp. Med., 1976, $120(2)$, 191-195_ During dietary treatment of a case of maple syrup urine disease, it was found that abnormal EEGs were observed when serum levels of leucine were abnormally high while those of valine and isoleucine were normal, and also when serum levels of valine and isoleucine were abnormally high while serum leucine levels were normal. _— EEG; maple syrup urine disease

In a case of maple syrup urine disease, a serial electroencephalographic study was done before and during a dietary treatment and a relation between the EEG changes and serum levels of the branched-chain amino acids was investigated.

\section{The Patient and Methods}

M.I., a 2-month-old boy was admitted to our University Hospital because of feeding difficulty and peculiar odor of the urine. He had four siblings, two of whom had died in the neonatal period from the same symptoms as those of the present patient.

The patient appeared well until the age of 7 days when he suddenly became difficult to feed. The patient's urine was noticed to have a peculiar odor at 5 weeks of life. On 73 days of life, the serum concentrations of leucine, isoleucine and valine were found to be $53.40,12.04$ and $16.44 \mathrm{mg} / 100 \mathrm{ml}$, respectively, while serum levels of other amino acids were all within normal ranges. Urinalysis revealed a positive reaction to the dinitrophenylhydrazin test. Maple syrup urine disease was diagnosed from these data.

As shown in Fig. 1, from 86 days of life, a dietary therapy with a special milk formula (Snow Brand Milk Products Co., Ltd., Tokyo, Japan), with the composition described in Table 1, was started. Fifteen per cent of this milk preparation was given in a daily amount ranging from 540 to $700 \mathrm{ml}$, giving 370 to $480 \mathrm{kcal}$ per day.

Four days after the institution of the dietary treatment, serum levels of both valine and isoleucine were decreased below the normal range, while the serum leacine level remained abnormally high. Then, isoleucine, $30-50 \mathrm{mg} / \mathrm{kg} / \mathrm{day}$, and valine $40-50 \mathrm{mg} / \mathrm{kg} /$ day, were added to the diet as shown in Fig. 1.

Received for publication, May 31, 1976.

* Partly supported by a Grant-in-Aid for Scientific Research from the Ministry of Education of Japan (No. 077045). 
Electroencephalograms were recorded using a 13-channel electroencephalograph ('Toshiba EEG 23A, Tokyo, Japan), in an awake state and in a natural sleep stage.

For the estimation of serum concentrations of amino acids, an autoanalyzer of amino acids (Hitachi KLA-3B, Tokyo, Japan) was used.

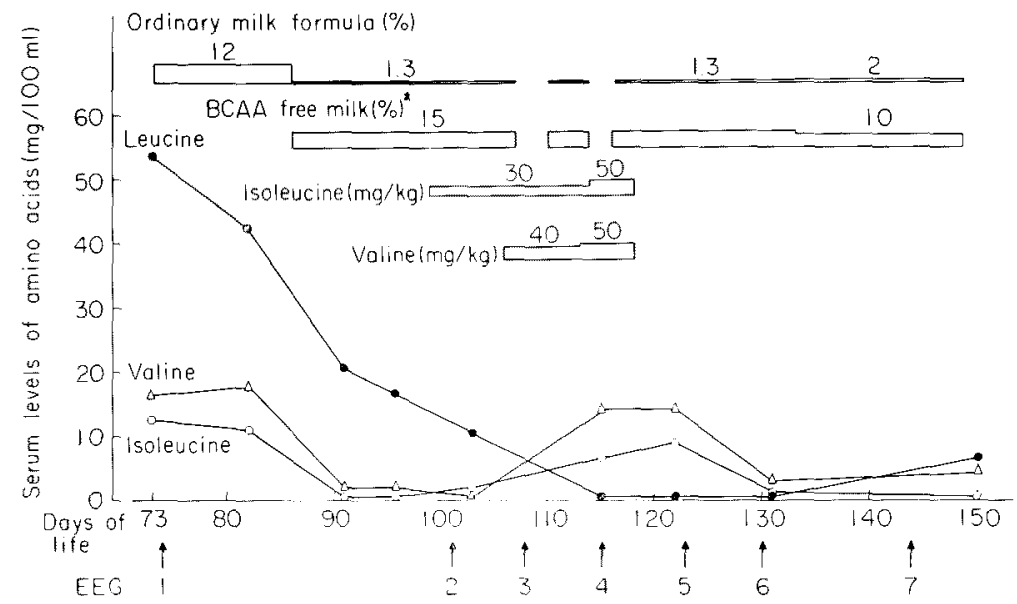

Fig. 1. Serum levels of the branched-chain amino acids before and during the dietary treatment with a branched-chain amino acids-free diet.

* BCAA free milk: a special diet with branched-chain amino acids-free milk (cf. Table 1).

TABLP 1. Composition of the branched-chain amino acids-free milk

\begin{tabular}{|c|c|c|c|}
\hline \multirow{3}{*}{$\begin{array}{l}\text { Protein (mixture of amino acids } \\
\text { except for leucine, isoleucine } \\
\text { and valine*) }\end{array}$} & & Amino acids contents & $\begin{array}{l}(\mathrm{mg} / 100 \mathrm{~g} \\
\text { milk) }\end{array}$ \\
\hline & & L-Alanine & 700 \\
\hline & $16.1 \%$ & L-Serine & 1,100 \\
\hline Fat & $17.0 \%$ & Glycine & 600 \\
\hline Carbohydrate & $59.4 \%$ & Sodium-L-aspartate & 1,600 \\
\hline Minerals & $4.5 \%$ & Sodium-L-glutamate & 4. 500 \\
\hline Water & $3.0 \%$ & L-Cystine & 1,000 \\
\hline & & L-Histidine monohydrochloride & 700 \\
\hline Vitamins and minerals & $\begin{array}{l}\text { (per } 100 \mathrm{~g} \\
\text { milk) }\end{array}$ & L-Proline & 1,600 \\
\hline Vitamin A & $1,800 \mathrm{IUt}$ & L-Phenylalanine & 1,000 \\
\hline Thiamine & $1.00 \mathrm{mg}$ & L-Tyrosine & 1,000 \\
\hline Piboflavin & $1.00 \mathrm{mg}$ & L-Threonine & 1,100 \\
\hline Pyridoxine & $0.45 \mathrm{mg}$ & L-Arginine monohydrochloride & 900 \\
\hline Ascorbic acid & $40.00 \mathrm{mg}$ & L-Lysine monohydrochloride & 1,300 \\
\hline Vitamin $\mathrm{D}$ & $300 \mathrm{IU}$ & L-Tryptophane & 400 \\
\hline Calcium pantothenate & $2.30 \mathrm{mg}$ & u-Methionine & 500 \\
\hline Nicotinamide & $0.55 \mathrm{mg}$ & Leucine & 0 \\
\hline Choline chloride & $20.00 \mathrm{mg}$ & Isoleucine & 0 \\
\hline & & Valine & 0 \\
\hline
\end{tabular}

* IU: International units.

\section{Resutts ANd Discussion}

The EEG findings in our own case in relation to the child's age are shown in Table 2 and Fig. 2. 
TABLE 2. EEG findings in our case of maple syrup urine disease

\begin{tabular}{|c|c|c|c|}
\hline $\begin{array}{l}\text { No. of } \\
\text { EEG }\end{array}$ & $\begin{array}{c}\text { Age of patient } \\
\text { (days) }\end{array}$ & $\begin{array}{l}\text { Date } \\
(1975)\end{array}$ & Findings \\
\hline 1 & 74 & Oct. 3 & $\begin{array}{l}\text { Periodic bursts of multiple-spike and } \\
\text { waves with suppression bursts. }\end{array}$ \\
\hline 2 & 101 & Oct. 30 & $\begin{array}{l}\text { Multiple-spike and waves and high } \\
\text { voltage slow waves. }\end{array}$ \\
\hline 3 & 108 & Nov. 6 & $\begin{array}{l}\text { Multiple-spike and waves and slow } \\
\text { waves. }\end{array}$ \\
\hline 4 & 115 & Nov. 13 & $\begin{array}{l}\text { Multiple-spike and waves in fronto- } \\
\text { central region. }\end{array}$ \\
\hline 5 & 123 & Not. 21 & $\begin{array}{l}\text { Spike discharges were seen only in } \\
\text { fronto-central region. }\end{array}$ \\
\hline 6 & 130 & Nov. 28 & $\begin{array}{l}\text { Spike discharges without slow waves } \\
\text { were searcely seen in frontal portion. }\end{array}$ \\
\hline 7 & 144 & Dec. 12 & No spike discharges, slight asymmetry. \\
\hline
\end{tabular}

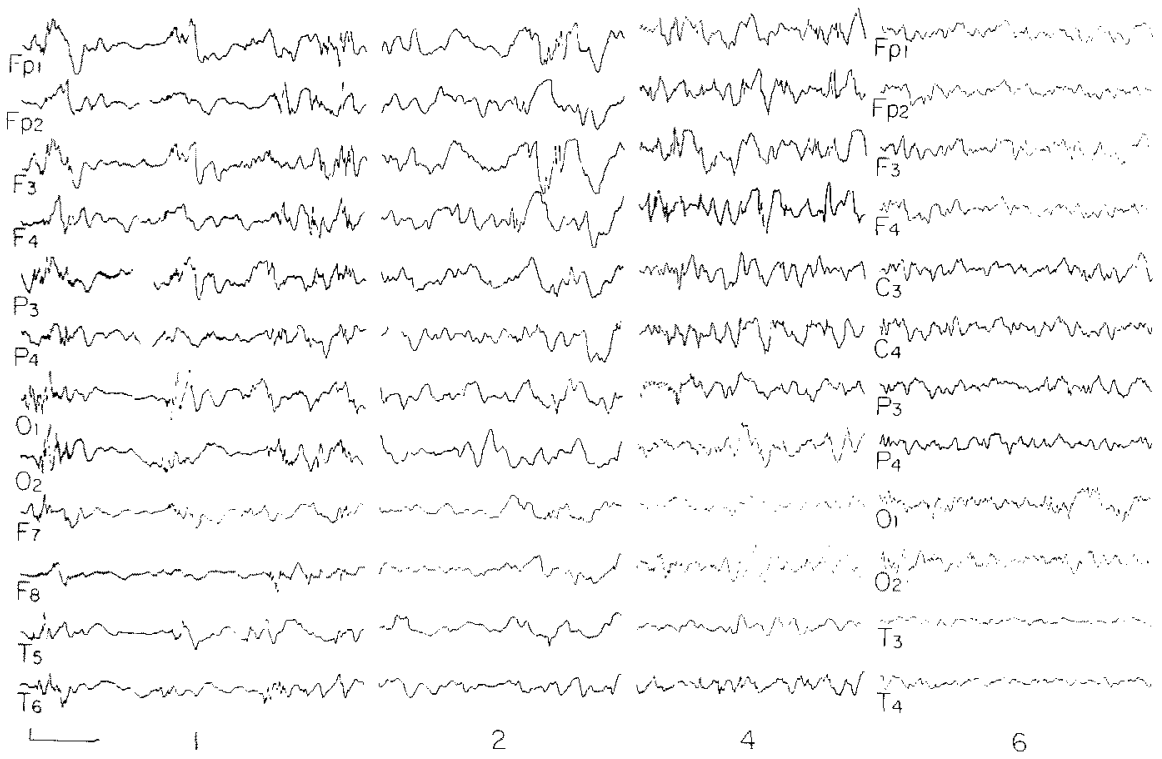

Fig. 2. Electroencephalograms of our case.

1: EEG taken at 74 days of age.

2: EEG taken at 101 days of age.

4: EEG taken at 115 days of age.

6: EEG taken at 130 days of age.

Serial changes of EEGs were as follows: The first tracing (74 days of life) which was taken before the dietary treatment showed periodic bursts of multiplespike and waves with suppression bursts. The second EEG (101 days of life) taken about 2 weeks after the institution of the dietary therapy showed multiplespike and waves and high voltage slow waves.

Spike and waves were still observed in the fourth EEG (115 days of life) taken when serum levels of valine and isoleucine were above the normal range. 
The sixth EEG (130 days of life) taken when all of the three branched-chain amino acids were within normal ranges showed scarce appearance of spike discharges without slow waves.

"Severely dysrhythmic" EEGs were reported in cases of maple syrup urine disease by several authors (Dancis et al. 1960; Morris et al. 1961; Silberman et al. 1961).

In 1969, Gaull reported a case of this disorder in which EEG with a high voltage triphasic pattern was observed when serum levels of the total branchedchain amino acids were abnormally high, while the EEG became normal when serum amino acid pattern was normalized after treatment with peritoneal dialysis.

TABLE 3. Serum levels of branched-chain amino acids of our patient $(\mathrm{mg} / 100 \mathrm{ml})$

\begin{tabular}{cccc}
\hline Days of life & Leucine & Isoleucine & Valine \\
\hline 73 & 53.40 & 12.04 & 16.44 \\
82 & 44.3 & 10.8 & 17.7 \\
91 & 20.4 & 0.19 & 1.82 \\
96 & 16.6 & 0.27 & 2.26 \\
103 & 10.3 & 1.70 & 0.77 \\
115 & 0.45 & 6.35 & 14.0 \\
122 & 0.54 & 8.72 & 14.3 \\
131 & 1.08 & 0.81 & 3.31 \\
150 & 6.58 & 0.10 & 4.43 \\
\hline
\end{tabular}

In 1971, Sonksen et al. investigated EEGs of 2 cases of maple syrup urine disease and described that abnormal EEGs of irregular $21 / 2-6 \mathrm{~Hz}$ activity were observed when the patients were critically ill, and that the EEGs were gradually improved when the clinical conditions of these patients were getting better after the exchange transfusion and peritoneal dialysis were performed.

In our case, it is worthy of notice that the abnormal EEGs were observed when serum leucine levels were abnormally high while serum levels of valine and isoleucine were normal (cf. EEG-2), and when serum levels of valine and isoleucine were abnormally high, while the serum leucine level was normal (cf. EEG-4); and that the almost normal EEG was found only when serum amino acid pattern became normal by a dietary treatment (cf. EEG-6). And the most severe changes in the EEG including periodic bursts of multiple-spike and waves with suppression bursts were observed when serum levels of leucine, isoleucine and valine were abnormally high (cf. EEG-1).

From view point of EEG changes and their relation to serum levels of the branched-chain amino acids, serum levels of all three branched-chain amino acids should be kept within the normal ranges by the dietary treatment, even though Snyderman et al. (1964) reported that acute symptoms such as ataxia, convulsions and coma were more directly related to excess of leucine than to that of valine and/or isoleucine in this disorder. 


\section{References}

1) Dancis, J., Levitz, M. \& Westall, R.G. (1960) Maple syrup urine disease: branchedchain keto-aciduria. Pediatrics, 25, 72-79.

2) Gaull, G.E. (1969) Pathogenesis of maple-syrup-urine disease: observations during dietary management and treatment of coma by peritoneal dialysis. Biochem. Med, , 3, 130-149.

3) Morris, M.D., Lewis, B.D., Doolan, P.D. \& Harper, H.A. (1961) Clinical and biochemical observations on an apparently neonatal variant of branched-chain ketoaciduria (maple syrup urine disease). Pediatrics, 28, 918-923.

4) Silberman, J., Dancis, J. \& Feigin, I. (1961) Neuropathological observations in maple syrup urine disease: 'branched chain ketoaciduria'. Arch. Neurol., 5, 351-363.

5) Snyderman, S.E., Norton, P.M., Roitman, E. \& Holt, L.E. (1964) Maple syrup urine disease, with particular reference to dietotherapy. Pediatrics, 34, 454-472.

6) Sonksen, P.M., Cottom, D.G. \& Harden, A. (1971) The evolution of the EEG in two patients with maple syrup urine disease (branched-chained ketonuria). Develop. Med. Child Neurol., 13, 606--612. 